\title{
Characterization of Water Sorption, Solubility and Filler Particles of Light-Cured Composite Resins
}

\author{
Sandrine Bittencourt BERGER ${ }^{1}$ \\ Alan Rodrigo Muniz PALIALOL ${ }^{1}$ \\ Vanessa CAVALLI ${ }^{2}$ \\ Marcelo GIANNINI ${ }^{1}$ \\ ${ }^{1}$ Department of Restorative Dentistry, Piracicaba Dental School, State University of Campinas, Campinas, SP, Brazil \\ ${ }^{2}$ Department of Restorative Dentistry, University of Taubaté, Taubaté, SP, Brazil
}

\begin{abstract}
The goals of this study were to measure the water sorption (WS) and solubility (SO) of 3 composite resins containing different filler contents. Additionally, the size, shape, type and other characteristics of fillers were analyzed by scanning electron microscopy (SEM). Three composites, classified according to filler size, were selected: Filtek Supreme nanofill (3M/ESPE), Esthet-X minifill (Dentsply/ Caulk) and Renamel microfill (Cosmedent Inc.). Ten disk-shaped specimens of each resin composite were made and stored in desiccators until constant mass was achieved. Specimens were then stored in water for 7 days, and the mass of each specimen was measured. The specimens were dried again and dried specimen mass determined. The WS and SO were calculated from these measurements. Data analyzed by one-way ANOVA and Tukey's post-hoc test $(\alpha=0.05)$. Composite filler particles were observed under SEM after removal of resin matrix by organic solvents. WS values were not significantly different among the resins; however, SO values were lower for Filtek Supreme. The materials presented differences in filler contents (e.g. particle size and shape). The composite resins had similar WS, while the SO was lower for the nanofill than for mini and microfill resins. The filler characteristics varied and were different among the materials
\end{abstract}

Key Words: resin composite, sorption, solubility, filler particles.

\section{INTRODUCTION}

In current clinical restorative treatment many types of resin composites are available for the replacement of natural tooth tissues. Composites consist mainly of filler particles and a resin matrix based on different monomers. For purposes of research, clinical applications and communications, composite resins are traditionally classified on the basis of filler particle size, i.e. macrofill, hybrid and microfill. However, a new classification of filler particle sizes could include the nanofillers, nanohybrids, and microhybrid or minifill composites (1-7).

The characterization and evaluation of resinbased material properties are assessed by flexural strengths, elasticity modulus, degree of conversion, hardness, wear resistance, polishability and other investigations (2,3,5-10). Water sorption and solubility are important properties of composite resins and influence their strength, abrasion resistance, volume and color stability (8,11-15). As a consequence of the high water sorption and solubility of restorative resins, studies have related a decreased mechanical properties and reduced longevity of composite restorations $(8,12,13,16)$.

As the filler characteristics of composites have been considered a significant factor in their rate of wear, surface roughness, esthetic results, water sorption(WS) and solubility (SO) $(11,13,17,18)$, the objectives of this study were to compare the WS and SO of 3 resin-based filling materials containing different filler contents. This investigation also analyzed filler sizes, shape, type and other characteristics of resins under scanning electron microscopy (SEM). The tested hypothesis was that filler characteristics may influence the WS and SO of resins.

\section{MATERIAL AND METHODS}

The compositions of the 3 composite resins tested are presented in Table 1. Composite resins were selected 
according to the filler size: Filtek Supreme nanofill (3M/ ESPE, St. Paul, MN, USA), Esthet-X minifill (Dentsply/Caulk, Milford, DE, USA) and Renamel microfill (Cosmedent Inc., Chicago, IL, USA).

For the WS and SO analyses, 10 disk-shaped specimens of each composite resin were prepared using Teflon molds $(0.8 \mathrm{~mm}$ in thickness and $6.0 \mathrm{~mm}$ in diameter). After filling the mold to excess, the material surface was covered with a polyester strip and glass slide, compressed to avoid porosities, and light-cured from the surface with a halogen light-curing unit (Optilux 501; Demetron/Kerr Corp., Orange, CA, USA). The resin disks were stored in a desiccator (Pyrex, São Paulo, SP, Brazil) at $37^{\circ} \mathrm{C}$ for $22 \mathrm{~h}$, followed by $2 \mathrm{~h}$ at $23^{\circ} \mathrm{C}$, until constant mass was achieved (m1). The masses of these completely dried specimens were recorded (Chyo Balance JK 180; Chyo Corp., Tokyo, Japan). Specimens were then stored for 7 days in water at $37^{\circ} \mathrm{C}$, and the saturated mass was measured (m2). Finally, the specimens were dried again in the desiccatoruntil obtaining constant mass and their masses were once again determined $(\mathrm{m} 3)$. The difference in mass between the initial dry and final dry mass represented the amount of SO (m1 - m3/volume of specimen), which was analyzed by one-way ANOVA and Tukey's post-hoc test $(\alpha=0.05)$. The difference in mass between saturated and final dry specimens provided sorption values ( $\mathrm{m} 2$ - m3/volume of specimen), which were analyzed by one-way ANOVA.

For evaluating the filler particles, 5 disk-shaped specimens of each composite resin were prepared using Teflon molds ( $3 \mathrm{~mm}$ thick and $5.0 \mathrm{~mm}$ in diameter) and light-cured for $5 \mathrm{~s}$ with the halogen light-curing unit. Each Filtek Supreme or Esthet-X composite resin disk was immersed for 1 week in $2 \mathrm{~mL}$ acetone, which was changed daily. For Renamel Microfill, the treatment was the same, but the organic solvent used was chloroform. Thereafter, the specimens were fixed in metallic stubs, sputter-coated with gold (MED 010; Baltec, Balzers, Leichtenstein) and observed with a scanning electron microscope (JSM-5600; JEOL Inc., Peabody, MA, USA). Representative areas showing the filler particles were photographed at $\times 1,000$ and $\times 2,500$ magnifications.

\section{RESULTS}

WS and SO mean values are presented in Table 2. The tested materials had statistically similar WS $(p>0.05)$, but differed significantly from each other with regard to water $\mathrm{SO}$, ANOVA revealed significant differences among the composites $(\mathrm{p}<0.0001)$. The SO of Filtek Supreme was lower than those of Esthet-X and Renamel Microfill, which presented similar mean $\mathrm{SO}$ values.

Figures 1 to 3 show the filler particles of Filtek Supreme, Esthet-X and Renamel Microfill, respectively. Fillers were irregular (Esthet-X and Renamel Microfill) or spherical (Filtek Supreme) in shape, depending on

Table 2. Mean values of water sorption and solubility $\left(\mu \mathrm{m} / \mathrm{mm}^{3}\right)$.

\begin{tabular}{lcc}
\hline Composite esin & Water sorption & Water solubility \\
\hline Filtek Supreme & $17.1(3.8) \mathrm{A}$ & $-4.0(2.9) \mathrm{B}$ \\
Esthet-X & $17.5(9.0) \mathrm{A}$ & $5.8(2.8) \mathrm{A}$ \\
Renamel Microfill & $20.3(4.4) \mathrm{A}$ & $4.8(2.4) \mathrm{A}$ \\
\hline
\end{tabular}

Means with the same letter within each column are not statistically different $(\alpha=0.05)$.

Table 1. Characteristics of composite resins tested.

\begin{tabular}{|c|c|c|c|c|}
\hline Material & Composition & Filler vol. (\%) & Filler wt. (\%) & Batch number \\
\hline $\begin{array}{l}\text { Filtek } \\
\text { Supreme }\end{array}$ & $\begin{array}{l}\text { Bis-EMA, BisGMA, TEGDMA, } \\
\text { non-agglomerated/non-aggregated } 20 \mathrm{~nm} \text { nanosilica filler, } \\
\text { agglomerated zirconia/silica nanocluster }\end{array}$ & 59.5 & 82 & $6 \mathrm{AL}$ \\
\hline $\begin{array}{l}\text { Renamel } \\
\text { Microfill }\end{array}$ & $\begin{array}{l}\text { Di urethane dimethacrylate, Butanediol dimethacrylate, } \\
\text { Multifunctional methacrylate ester, pyrogenic silicic acid filler }\end{array}$ & 59 & 60 & 053819K \\
\hline Esthet-X & $\begin{array}{l}\text { Urethane modified Bis-GMA dimethacrylate, } \\
\text { photoinitiators, stabilizers, } \\
\text { barium boron fluoroalumino silicate glass, amorphous silica }\end{array}$ & 60 & 77 & 0510281 \\
\hline
\end{tabular}



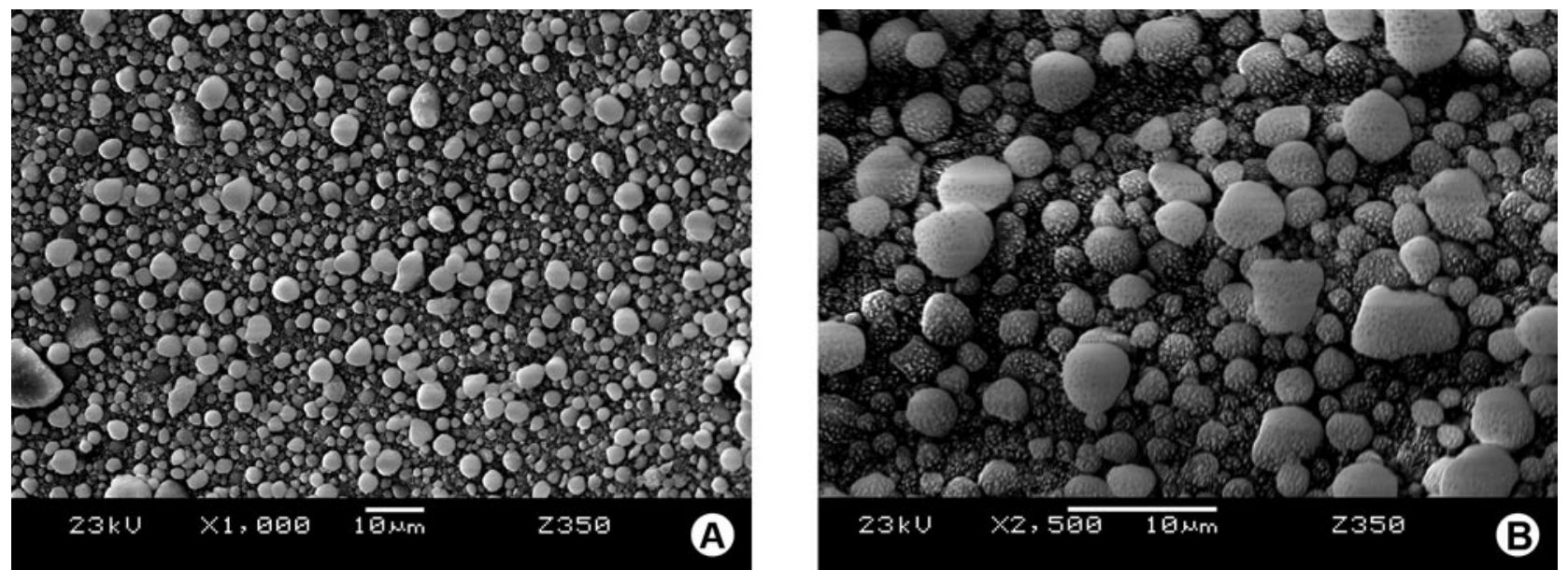

Figure 1. SEM micrograph of Filtek Supreme composite resin $(A=\times 1,000$ and $B=\times 2,500$ magnifications). Agglomerated zirconia/ silica spherical nanocluster of 1 to $4 \mu \mathrm{m}$ can be noted.
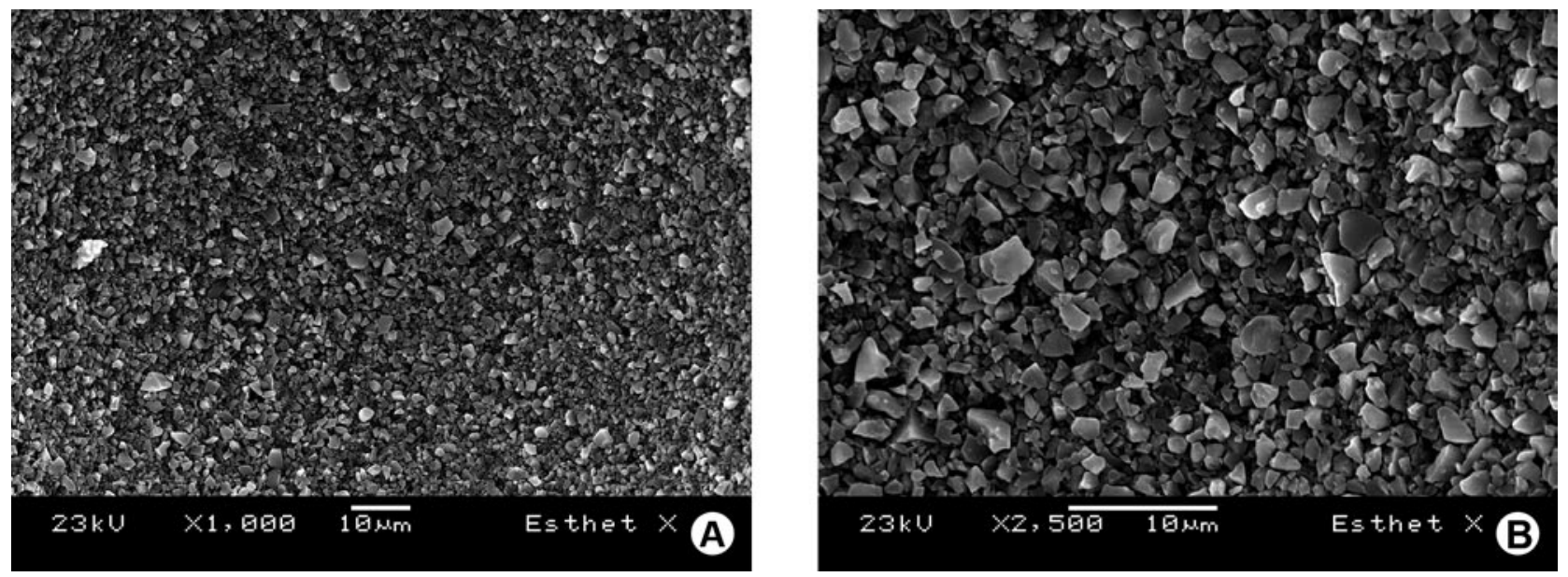

Figure 2. SEM micrograph of Esthet-X composite resin $(A=\times 1,000$ and $B=\times 2,500$ magnifications). Irregular-shaped filler particles can be observed, ranging from 0.5 to $3 \mu \mathrm{m}$.
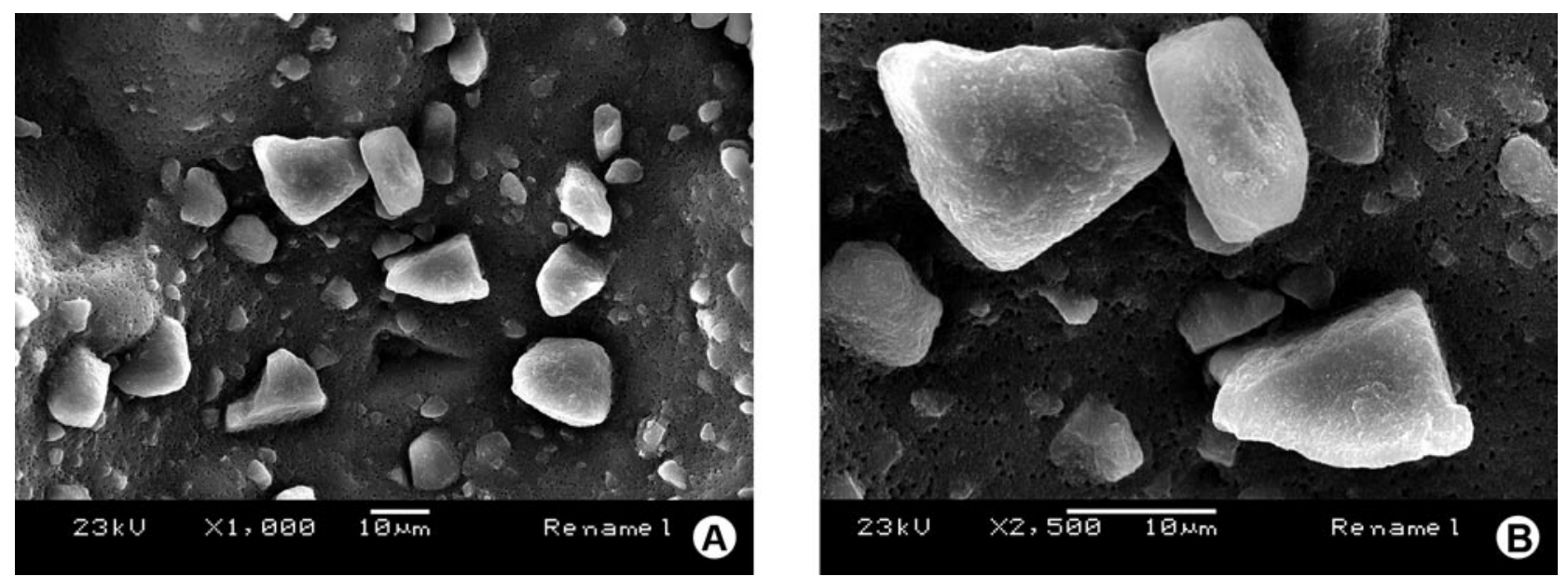

Figure 3. SEM micrograph of Renamel Microfill composite resin $(A=\times 1,000$ and $B=\times 2,500$ magnifications). Irregular-shaped filler particles can be observed, ranging from 0.5 to $10 \mu \mathrm{m}$. 
the manufacturer. Spherical agglomerates of 1 to $4 \mu \mathrm{m}$ nano-sized particles can be observed in the composition of Filtek Supreme (Fig. 1A). Nanoparticles were discrete nonagglomerated and nonaggregated particles situated among and over nanoclusters or spherical agglomerates (Fig. 1B). Esthet-X presented irregularshaped filler particles, ranging from 0.5 to $3 \mu \mathrm{m}$. The average size of the fillers was 0.5 to $1 \mu \mathrm{m}$ (Fig. $2 \mathrm{~A}$ and 2B). Distribution of filler particles of Renamel Microfill (Cosmedent Inc.) was not uniform and the composite contained many particles larger than $1 \mu \mathrm{m}(<10 \mu \mathrm{m})$, but the predominance of particles were of one micron or less (Fig. 3A and 3B).

\section{DISCUSSION}

The amount of water that composite resins can absorb depends on the hydrophilicity of polymeric matrices and filler composition $(8,9,18,19)$. The composites tested in this study showed similar WS mean values after one week of water storage and these values can be considered as lower and adequate for resin-based filler materials. The WS values ranged from 17.1 to $20.3 \mu \mathrm{m} /$ $\mathrm{mm}^{3}$ and were lower than those required by the ISO 4049 standard, which establishes that the maximum WS value is $40 \mu \mathrm{m} / \mathrm{mm}^{3}$.

The 3 composites (Filtek Supreme, Renamel Microfill and Esthet-X) contain BisGMA and other di- and methacrylate monomers (Bis-EMA, TEGDMA and UDMA), and these different resin matrices did not seem to influence the results of WS analyzes. Most resin-based composites are Bis-GMA-based materials and the chemistry of the monomers present in the matrix is a key factor to the hydrophilic nature of the polymer (9). The high viscosity of the polymer requires the addition of diluent monomers, such as TEG-DMA. Such diluent monomers, coupled with the presence of hydroxyl groups in the Bis-GMA molecule, result in an increase in WS. WS can promote the expansion of the restoration, which is detrimental to its longevity (14).

Da Silva et al. (6) showed a correlation between $\mathrm{SO}$ and degree of conversion in nanofilled and hybrid composites. Nevertheless, no correlation was found between degree of conversion and saliva sorption for the same materials. Therefore, it may be assumed that the increase in the degree of conversion reduced SO. Since SO is reflected by amount of leachable unreacted monomers, the high degree of conversion reduced the SO because the amount of unreacted monomers available for leaching out was lower due to the high percentage of reacted aliphatic $\mathrm{C}=\mathrm{C}$ bonds from the dimethacrylate monomers. However, the nanofilled composite presented a higher SO than the hybrid resin, in contrast to the data of the present study.

The water SO mean values presented by the composite resins tested varied from -4.0 to $5.8 \mu \mathrm{m} / \mathrm{mm}^{3}$; these values were lower than the maximum value established by the ISO 4049 standard $\left(<7.5 \mu \mathrm{m} / \mathrm{mm}^{3}\right)$. Filtek Supreme demonstrated a negative value, indicating that, possibly not all of the absorbed water was removed by the drying process or that the any reaction was incomplete, thus, increasing the mass of the composite (4). Renamel Microfill and Esthet-X had similar SO means, which were higher than that of Filtek Supreme.

Besides unreacted monomers, inorganic ions present as fillers within composites can leach into the surrounding environment. In addition, water in contact with silica filler surfaces can break siloxane bonds and the hydrolysis induces debonding of the filler particles, increasing the mass loss of the composite. Yap and Wee (18) showed a correlation between filler load and WS and SO when comparing a highly filled composite (Surefil; Dentsply/Caulk, 66\% by volume) and 3 other materials; one microfilled (Silux Plus; 3M/ESPE) and 2 microhybrid resins (Z100; 3M/ESPE and Ariston $\mathrm{pHc}$ - Ivoclar, Vivadent). The composites used in this study contain similar filler content by volume (59 to $60 \%$ of filler), but the size, shape and type of filler differed among materials.

Dental composites have used strontium glass, barium glass, quartz, borosilicate glass, ceramic, silica and prepolymerized resin as filler particles $(1,2,20)$. Filtek Supreme contains $20 \mathrm{~nm}$ nanosilica spherical fillers (non-agglomerated/non-aggregated) and agglomerated zirconia/silica spherical nanoclusters of 1 to $4 \mu \mathrm{m}$ (Fig. 1). The fillers of Esthet-X and Renamel Microfill have irregular shapes and are composed of glass and silica particles (Figs. 2 and 3). However, the average size of the filler particles of the Esthet-X composite resin is lower than that of Renamel Microfill.

In conclusion, filler particles seem to have little influence upon WS and SO. The tested composite resins had similar WS characteristics, while the SO of the nanofilled composite resin was lower than those of the minifill and microfilled composites. 


\section{RESUMO}

Os objetivos deste estudo foram determinar a sorção de água (SA) e solubilidade (SO) de 3 resinas compostas que contêm diferentes conteúdos de partículas de carga. Adicionalmente, o tamanho, formato, tipo e outras características das partículas foram analisados em microscopia eletrônica de varredura (MEV). As resinas foram selecionadas de acordo com o tamanho das partículas: Filtek Supreme nanoparticulado (3M ESPE), EsthetX microhíbrido (Dentsply Caulk) e Renamel microparticulado (Cosmedent Inc.). Dez espécimes com formato de disco de cada compósito foram confeccionados e armazenados em dessecador até obtenção de massa constante. Em seguida, os espécimes foram armazenados em água por 7 dias e a massa mensurada novamente. Os espécimes foram desidratados novamente e a massa final mensurada. A SA e a SO foram calculados a partir destas medidas. As partículas de carga dos compósitos foram observadas em MEV, após a remoção da matriz orgânica com solventes orgânicos. Os dados foram analisados por ANOVA e teste de Tukey $(\alpha=0.05)$. As médias de SA das resinas compostas foram semelhantes. A SO foi menor para o compósito Filtek Supreme. Os materiais contêm diferentes conteúdos de carga, em termos de formato e tamanho das partículas. As resinas compostas mostraram similar SA, enquanto o compósito nanoparticulado apresentou a menor SO. As características das partículas de carga foram diferentes entre os compósitos estudados.

\section{ACKNOWLEDGEMENTS}

This study was supported by grants from SAE/PRP, UNICAMP, FAPESP (\#07/54784-1) and CNPq (\#303587/2007-5), Brazil.

\section{REFERENCES}

1. Da Costa J, Ferracane J, Paravina RD, Mazur RF, Roeder L. The effect of different polishing systems on surface roughness and gloss of various resin composites. J Esthet Restor Dent 2007;19:214-224.

2. Jung M, Sehr K, Klimek J. Surface texture of four nanofilled and one hybrid composite after finishing. Oper Dent 2007;32:45-52.

3. Senawongse P, Pongprueksa P. Surface roughness of nanofill and nanohybrid resin composites after polishing and brushing. J Esthet Restor Dent 2007;19:265-273.

4. Janda R, Roulet JF, Latta M, Rüttermann S. Water sorption and solubility of contemporary resin-based filling materials. J Biomed Mater Res Part B: Appl Biomater 2007;82B:545-551.
5. Korkmaz Y, Ozel E, Attar N, Aksoy G. The influence of one-step polishing systems on the surface roughness and microhardness of nanocomposites. Oper Dent 2008;33:44-50.

6. da Silva EM, Almeida GS, Poskus LT, Guimarães JGA. Relationship between the degree of conversion, solubility and salivary sorption of a hybrid and a nanofilled resin composite. J Appl Oral Sci 2008;16:161-166.

7. Ruttermann S, Wandrey C, Raab WHM, Janda R. Novel nanoparticles as fillers for an experimental resin-based restorative material. Acta Biomaterialia 2008;4:1846-1853.

8. Sideridou I, Tserki V, Papanastasiou G. Study of water sorption, solubility and modulus of elasticity of light-cured dimethacrylatebased dental resins. Biomaterials 2003;24:655-665.

9. Ito S, Hashimoto M, Wadgaonkar B, Svizero N, Carvalho RM, Yiu C, et al.. Effects of resin hydrophilicity on water sorption and changes in modulus of elasticity. Biomaterials 2005;26:6449-6459.

10. Dall'Magro E, Sinhoreti MAC, Correr AB, Correr-Sobrinho L, Consani S, Puppin-Rontani RM. Effect of different initial light intensity by the soft-start photoactivation on the bond strength and Knoop hardness of a dental composite. Braz Dent J 2007;18:107-112.

11. Shintani H, Satou N, Yukihiro A, Satou J, Yamane I, Kouzai T, et al.. Water sorption, solubility and staining properties of microfilled resins polished by various methods. Dent Mater J 1985;4:54-62.

12. Musanje L, Shu M, Darvell BW. Water sorption and mechanical behaviour of cosmetic direct restorative materials in artificial saliva. Dent Mater 2001;17:394-401.

13. Göhring TN, Besek MJ, Schmidlin PR. Attritional wear and abrasive surface alterations of composite resin materials in vitro. J Dent 2002;30:119-127.

14. Martin N, Jedynakiewicz NM, Fisher AC. Hygroscopic expansion and solubility of composite restoratives. Dent Mater 2003;19:77-86.

15. Nagem Filho H, D'Azevedo MT, Nagem HD, Marsola FP. Surface roughness of composite resins after finishing and polishing. Braz Dent J 2003;14:37-41.

16. Söderholm KJ, Roberts MJ. Influence of water exposure on the tensile strength of composites. J Dent Res 1990;69:1812-1816.

17. Oysaed H, Ruyter IE. Water sorption and filler characteristics of composites for use in posterior teeth. J Dent Res 1986;65:1315-1318

18. Yap AU, Wee KE. Effects of cyclic temperature changes on water sorption and solubility of composite restoratives. Oper Dent 2002;27:147-153.

19. Kalachandra S, Wilson TW. Water sorption and mechanical properties of light-cured proprietary composite tooth restorative materials. Biomaterials 1992;13:105-109.

20. Puckett AD, Fitchie JG, Kirk PC, Gamblin J. Direct composite restorative materials. Dent Clin North Am 2007;51:659-675.

Accepted October 16, 2009 